GEOLOGICAL SURVEY CIRCULAR 684

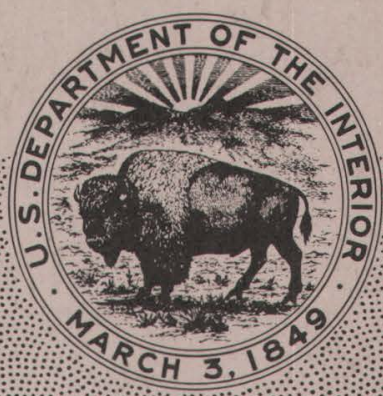

Mineral Resource Potential of the Stillwater Complex and Adjacent Rocks in the Northern Part of the Mount Wood and Mount Douglas Quadrangles, Southwestern Montana 

Mineral Resource Potential of the Stillwater Complex and Adjacent Rocks in the Northern Part of the Mount Wood and Mount Douglas Quadrangles, Southwestern Montana

By Norman J Page and John C. Dohrenwend

GEOLOGICAL SURVEY CIRCULAR 684 
United States Department of the Interior ROGERS C. B. MORTON, Secretary

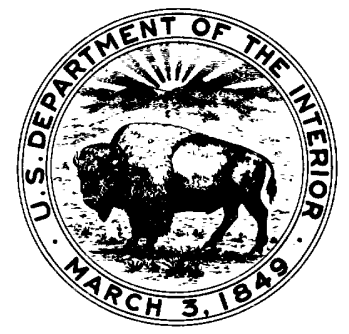

Geological Survey

V. E. McKelvey, Director 


\section{CONTENTS}

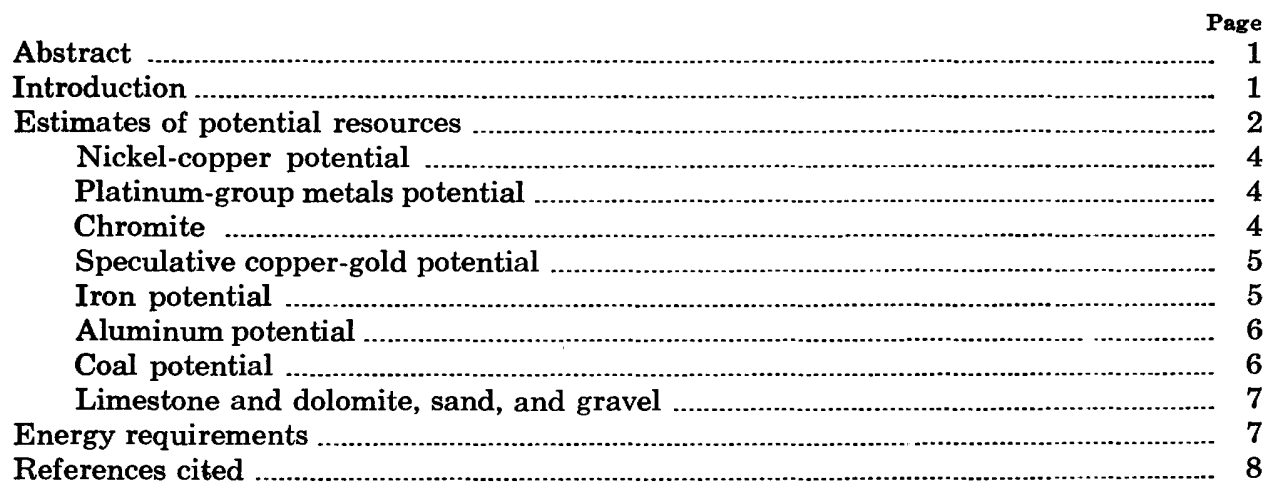

\section{ILLUSTRATION}

FIGURE 1. Map of potential resources in the northern parts of the Mount Wood

\section{TABLES}

TABLE 1. Generalized stratigraphic terminology used for the Stillwater area

Page

2. Estimated chromite resource potential for the Stillwater Complex

4

3. Estimated potential aluminum resources for the anorthosites of the Stillwater Complex

4. Inferred coal resources of the Stillwater area 


\title{
Mineral Resource Potential of the Stillwater Complex and Adjacent Rocks in the Northern Part of the Mount Wood and Mount Douglas Quadrangles, Southwestern Montana
}

\author{
By Norman J Page and John C. Dohrenwend
}

\begin{abstract}
The Stillwater Complex contains the largest potential chromite and platinum metal resources and second largest nickel resources in the United States. The Ultramafic zone has produced about 900,000 long tons of chromite concentrate and contains unmined reserves equivalent to 2,520,000 long tons of $\mathrm{Cr}_{2} \mathrm{O}_{3}$. Nickel and copper sulfide minerals that occur in the Basal zone and adjacent hornfelsed metasedimentary rocks represent one of the largest nickel potentials in the United States-a known reserve of 150 million tons of 0.25 percent nickel and 0.25 percent copper. The complex has been estimated to contain the largest potential source of platinum metals in the United States-possibly over 150 million troy ounces in the lower chromite zones and the Basal zone. In addition, the anorthosites in the Banded and Upper zones are reported to represent a potential alumina resource of almost 2 billion tons. An iron-formation also is present in the adjacent Precambrian metasedimentary rocks, and a coal bed is present in the Upper Cretaceous Eagle Sandstone nearby. The eventual utilization of these resources depends on the availability of large quantities of energy, and thus they may not be recovered unless new sources of energy or new recovery techniques are developed.
\end{abstract}

\section{INTRODUCTION}

Within the last few years, it has become increasingly important to develop quantitative estimates of potential mineral resources for the United States. Resources were defined by Theobald, Schweinfurth, and Duncan (1972) as all minerals and rocks usable by man now or in the future. They included as resources (1) currently known and recoverable reserves, (2) hypothetical and speculative undiscovered resources that may be recoverable if found, and (3) identified and undiscovered resources that require changes in economic conditions or technology to become recoverable. These categories consider both the degree of certainty of finding the resource and the feasibility of economically recovering it; diagrams embodying these concepts were presented by McKelvey (1973) and Brobst and Pratt (1973). Most frequently, this approach results in sizable resource estimates, most of which are in the category of undiscovered resources requiring changes in economics or technology to recover the material. (See, for example, Theobald and others, 1972.) In addition, these estimates for undiscovered material commonly are pooled, thus applying to a large land area with little indication of where to search.

The area covered in this report, approximately 185 square miles, is in the northern part of the Mount Wood and Mount Douglas quadrangles, southwestern Montana (fig. 1). The region contains known mineral resources, some of which were mined in the past and on which previous investigators (for example, Jackson, 1968; Cornwall, 1966; Combo and others, 1949; Westgate, 1921) based evaluations of reserves of particular commodities. This report defines specific areas of potential resources and evaluates their magnitude. Because of the fairly extensive geologic knowledge of the area (intensive investigations have been carried on since 1916), most of the resources considered here would be categorized as identified resources and hypothetical undiscovered resources, but the fact they are not presently being mined indicates they have varying degrees of economic recovery. As will be shown, relatively high estimates of potential resources result from considering average grade, either known or reasonably inferred from available data and the area or volume of material present for exploitation. 
Yet, even in an area for which the geology is fairly well known, the bulk of the potential resources are not available, nor will they become available for man's use without major economic and technologic changes.

\section{ESTIMATES OF POTENTIAL RESOURCES}

An evaluation of blocks of ground containing potential identified or hypothetical and speculative resources for the northern halves of the Mount Wood and Mount Douglas 15-minute quadrangles,
Montana, is shown in figure 1. This map, containing the Stillwater Complex, delineates areas in which the resource potential for a particular commodity is inferred to be high, moderate, low, or nonexistent, on the basis of present geologic information. The map is intended to be only a preliminary evaluation of the Stillwater area. Factors that have entered into this evaluation are (1) known mines, their production, reserves, and geologic environment, (2) prospects known before 1964, their potential production and geologic en-

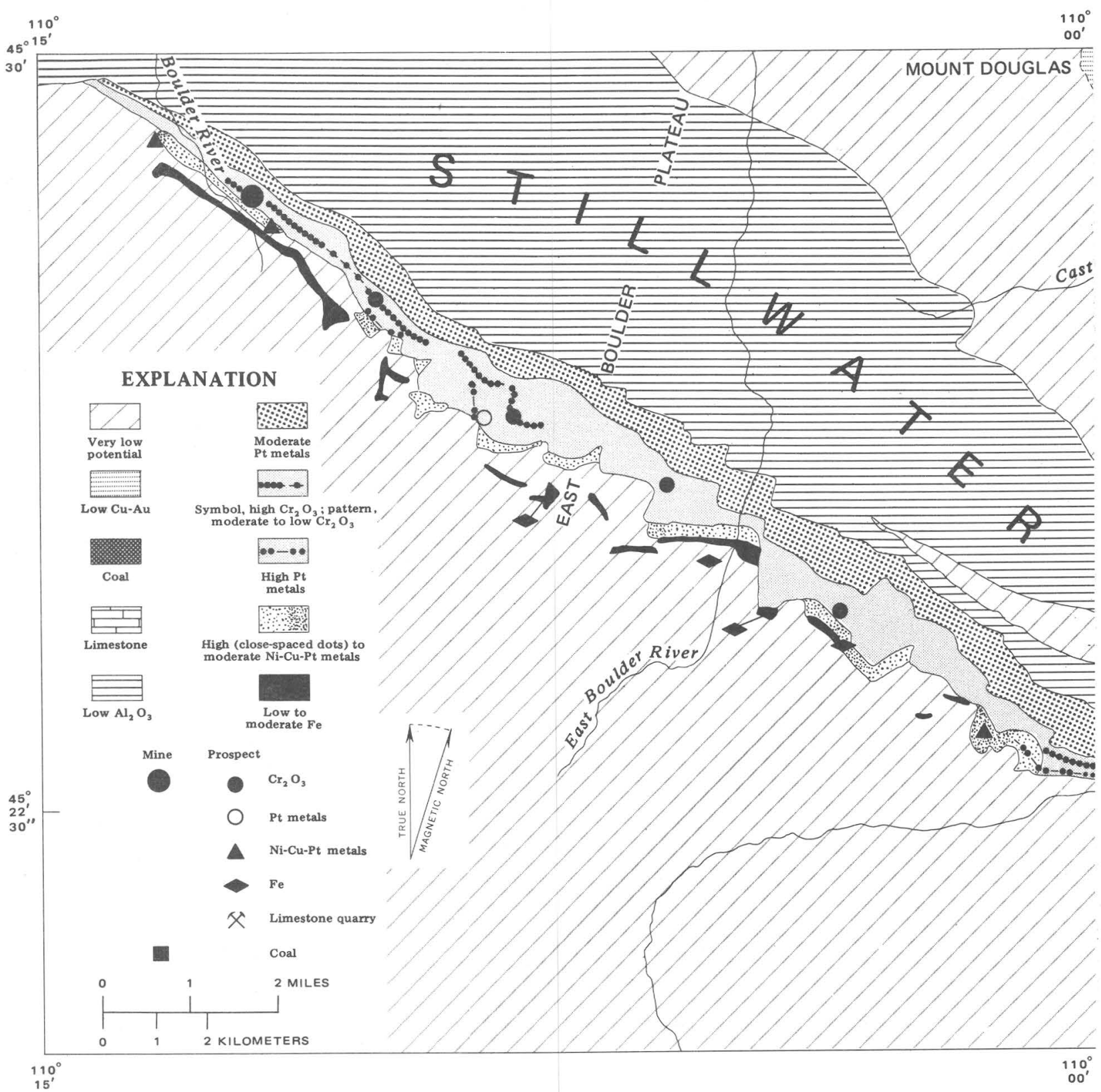

FIGURE 1.-Map of potential resources in the northern parts of 
vironment, (3) areas of mining company exploration since 1964, (4) geochemical, mineralogic, and petrologic studies, (5) geologic mapping and inference, and (6) a moderate amount of speculation and geologic extension of known occurrences. In constructing the map, the geologic maps of the Mount Wood and Mount Douglas 15-minute quadrangles (Page and others, 1973a, b) were used as a base. Data from open-file aeromagnetic maps by the U.S. Geological Survey (1971) were also incorporated.
The northern parts of the Mount Wood and Mount Douglas 15-minute quadrangles and parts of the McLeod Basin and Mount Rae 71/2-minute quadrangles in southwestern Montana contain a variety of rock types and differ in degree of geologic complexity. The dominant unit is the tabular mass of mafic and ultramafic rocks that forms the Stillwater Complex; it intrudes Precambrian metasedimentary rocks and is overlain by Paleozoic, Mesozoic, and Cenozoic sedimentary rocks. Detailed geologic and stratigraphic relations of

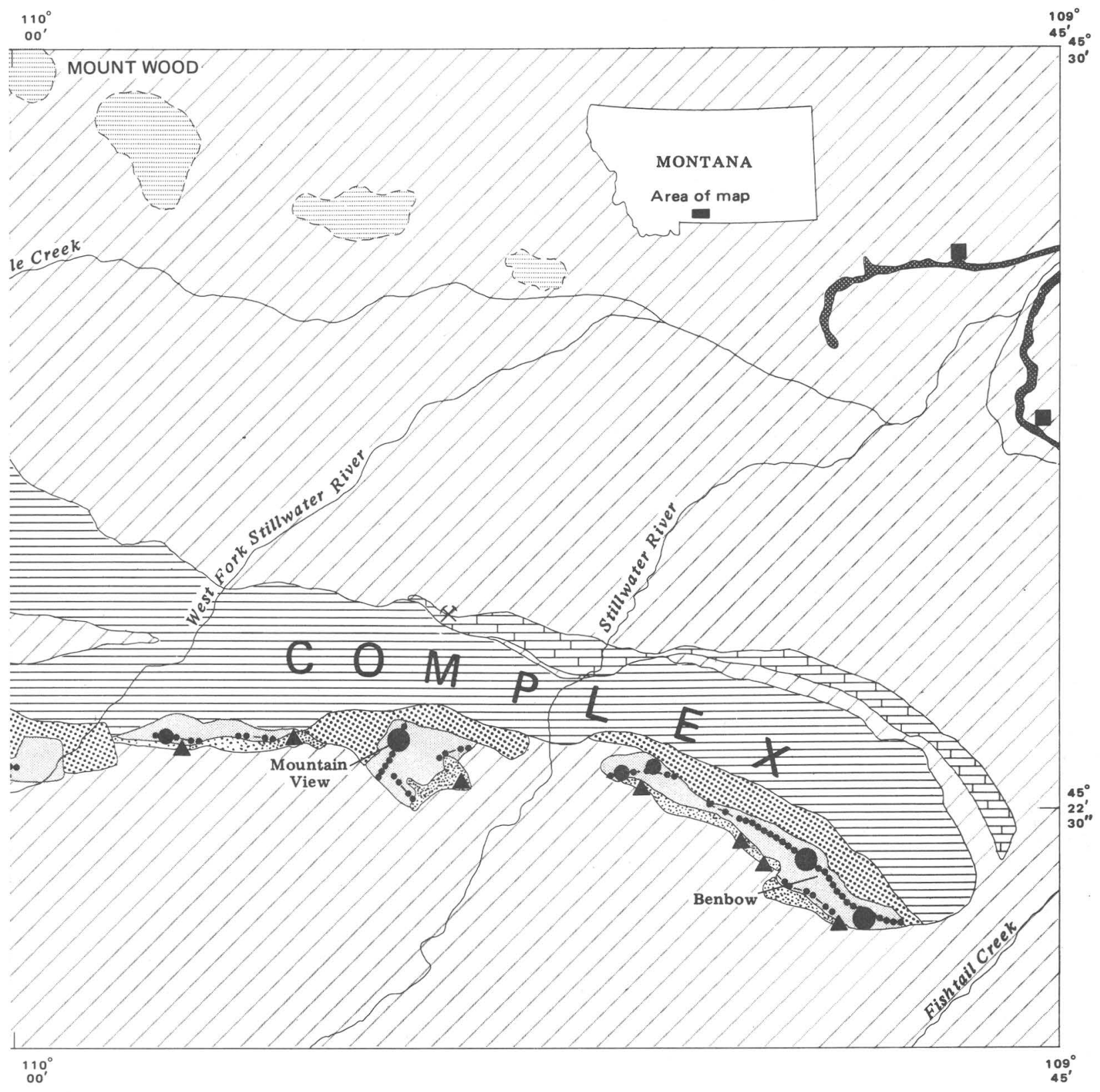

the Mount Wood and Mount Douglas quadrangles, Montana. 
the area were given by Page and Nokleberg (1970, 1972) and Page, Simons, and Dohrenwend (1973a, b). The Stillwater Complex was divided into four informal stratigraphic units on the basis of the early work of Peoples (1936), Jones, Peoples, and Howland (1960), Hess (1960), and Jackson (1961) and the later mapping of Page and Nokleberg $(1970,1972)$. The stratigraphy terminology is summarized in table 1. Only those units that are pertinent to the resource analysis are included.

TABLE 1.-Generalized stratigraphic terminology used for the Stillwater area

\begin{tabular}{|c|c|}
\hline Major units & Minor units \\
\hline $\begin{array}{l}\text { Sedimentary and igneous } \\
\text { rocks of Cenozoic, } \\
\text { Mesozoic, and } \\
\text { Paleozic age. }\end{array}$ & $\begin{array}{l}\text { Intrusive rocks of inter- } \\
\text { mediate composition } \\
\text { (Tertiary). } \\
\text { Eagle Sandstone (Upper } \\
\text { Cretaceous). } \\
\text { Madison Limestone } \\
\text { (Mississippian). }\end{array}$ \\
\hline $\left.\begin{array}{l}\text { Stillwater Complex } \\
\text { (Precambrian) } \\
\text { Upper zone } \\
\text { Banded zone }\end{array}\right\}$ & $\begin{array}{l}\text { Anorthosites, gabbros, } \\
\text { and norites. }\end{array}$ \\
\hline $\begin{array}{l}\text { Ultramafic zone: } \\
\text { Bronzitite member } \\
\text { Peridotite member } \\
\text { Basal zone. }\end{array}$ & $\left\{\begin{array}{l}\text { Contains about } 15 \text { cyclic } \\
\text { units, } 13 \text { of which have a } \\
\text { chromitite zone and are } \\
\text { labeled A through } K \\
\text { sequentially from the } \\
\text { base upward. }\end{array}\right.$ \\
\hline $\begin{array}{l}\text { Metasedimentary rocks } \\
\text { (Precambrian) meta- } \\
\text { morphosed to pyroxene } \\
\text { hornfels facies rocks. }\end{array}$ & Iron-formation. \\
\hline
\end{tabular}

\section{NICKEL-COPPER POTENTIAL}

The major nickel-copper potential of the area is from sulfide mineralization associated with the Basal zone of the Stillwater Complex (fig. 1). Howland (1933) was one of the first to describe occurrences of nickel and copper sulfides, and the Anaconda Co., the U.S. Geological Survey, and the U.S. Bureau of Mines explored the Mouat nickel deposit on the west side of the Stillwater River between 1937 and 1941 (Cornwall, 1966). Nickel and copper prospects known before 1964, some of which are shown in figure 1, are abundant in and adjacent to the Basal zone. From 1966 to 1972, five major mining companies (Dayton, 1971) began exploration programs in the area by means of geochemical and geophysical prospecting, trenching, drilling, tunneling, and metallurgical sample testing. Surface exposures of sulfide minerals and oxide gossans suggest that most of the Basal zone and adjoining metasedimentary rocks have a moderate to high resource potential for nickel and copper and for byproduct platinum metals and possibly cobalt. Reserves of 150 million tons of 0.25 percent nickel and 0.25 percent copper ore are known (Dayton, 1971) and are present mainly in the area adjacent to the Stillwater River. A more speculative resource estimate would be obtained by multiplying the reserves by a factor between 2 and 10 .

\section{PLATINUM-GROUP METALS POTENTIAL}

The estimated total platinum metals potential of the Stillwater Complex probably exceeds 150 million troy ounces. Platinum metals have been known to occur in the complex since the initial work of Howland (1933) and Howland, Peoples, and Sampson (1936). Studies by Page and Jackson (1967), Leonard, Desborough, and Page (1969), Grimaldi and Schnepfe (1969), Greenland, Rowe, and Dinnin (1971, table 2), Page, Riley, and Haffty (1969, 1971, 1972), Page (1971), and Page, Shimek, and Huffman (1972) documented some of the occurrences of platinum metal and minerals. On the basis of these studies, the A chromitite zone (see table 1) averages about $0.10 \mathrm{oz} /$ ton and attains a maximum known value of $0.60 \mathrm{oz} /$ ton of platinum, palladium, and rhodium; the B zone contains a slightly smaller amount of platinum metals. Therefore, the lower two chromitite zones of the Peridotite member, A and $\mathrm{B}$, are considered to have a high platinum potential, and the other chromite zones a low to moderate potential (fig. 1). The Basal zone thus probably contains large tonnages of low-grade material for which Page, Clark, Desborough, and Parker (1973) estimated the grade to be 0.5 parts per million platinum metals with a moderate to high potential. Platinum metals are also known to be present in sulfide zones in the Banded and Upper zones of the complex (Howland, 1933) and are suspected to be present in the pegmatitic phases of the Bronzitite member of the Ultramafic zone. Both of these areas have been assigned a low to moderate platinum resource potential (fig. 1).

\section{CHROMITE}

The total potential chromite resources in the Stillwater Complex are estimated to be approximately 7.9 million short tons of $\mathrm{Cr}_{2} \mathrm{O}_{3}$, all derived from the $\mathrm{G}$ and $\mathrm{H}$ chromitite zones. In addition to the potential resources, Jackson (1968) estimated that there are 2.8 million short tons of reserves in the Benbow and Mountain View areas. 
Jackson (1968, p. 1509-1510) indicated that the thickest chromite zone is the $\mathrm{G}$ zone followed by the $\mathrm{H}$ zone, and that the highest grade chromite is in the $\mathrm{H}$ zone followed by the $\mathrm{G}$ zone. The maximum $\mathrm{Cr} / \mathrm{Fe}$ ratio lies between 1.20 and 2.33 as determined on purified chromite (Jackson, 1968), and therefore milling techniques would produce concentrates of a slightly lower grade. In figure 1, the areas where these zones are known to occur are considered to be the richest of the potential chromite resources and are assigned a high potential. Since other chromite zones occur in the lower parts of the cyclic units within the Peridotite member, the area encompassed by the Peridotite member was assigned a low to moderate chromite resource potential. The other rock units do not contain significant amounts of $\mathrm{Cr}_{2} \mathrm{O}_{3}$ in any form and therefore have no chromite potential.

The volume of the potential chromite resource was then calculated on the basis of the detailed mapping by U.S. Geological Survey personnel since 1930, summarized on the maps of Page and Nokleberg (1970, 1972). The length, average thickness, and average $\mathrm{Cr}_{2} \mathrm{O}_{3}$ content of known occurrences of the $\mathrm{G}$ and $\mathrm{H}$ chromite zones were compiled and were extrapolated into covered areas along the strike of the complex. From the estimated volume a recoverable chromite tonnage to several depth categories was obtained, which includes factors derived from the following assumptions: (1) Significant concentrations of chromite occur only in the $\mathrm{G}$ and $\mathrm{H}$ chromitites; the presence of other, narrower chromite zones and widely disseminated chromite was ignored, (2) the measured dips of the chromitites range from less than $20^{\circ}$ to vertical, and the average dip throughout the complex approximates $60^{\circ}$, (3) the specific gravity of the chromite in $G$ and $H$ chromitites is approximately 4.5, (4) the aggregate thickness of the significant chromite zones $(2 \mathrm{ft}$ or $0.61 \mathrm{~m}$ ) does not vary by more than 50 percent from the average measured thickness for the western half of the complex, (5) the average $\mathrm{Cr}_{2} \mathrm{O}_{3}$ content is assumed to be 22 percent for the $\mathrm{G}$ and $\mathrm{H}$ chromitites between Benbow and Mountain View and 20 percent from Mountain View to the western end, on the basis of assays of Wimmler (1948) and others, and (6) the recovery rate for normal mining operations would approximate 50 percent.

The total potential chromite resources in the Stillwater Complex derived from these calcula- tions amount to approximately 7.9 million short tons of $\mathrm{Cr}_{2} \mathrm{O}_{3}$. A breakdown of this estimate by area and depth category is presented in table 2. This estimate does not include 2.8 million short

TABLE 2.-Estimated chromite resource potential for the Stillwater Complex

\begin{tabular}{|c|c|c|}
\hline & $\mathrm{Cr}_{2} \mathrm{O}_{3}$, in th & $\begin{array}{l}\text { of short tons, } \\
\text { of - }\end{array}$ \\
\hline & $\begin{array}{l}0-1.000 \mathrm{ft} \\
(304.8 \mathrm{~m})\end{array}$ & $\begin{array}{c}1,000-2,000 \mathrm{ft} \\
(609.6 \mathrm{~m})\end{array}$ \\
\hline $\begin{array}{l}\text { West of Mountain View } \\
\text { (Mouat to Sampson) } \\
\text { Benbow to Mountain View..... }\end{array}$ & $\begin{array}{l}2,300 \\
1,500 \\
\end{array}$ & $\begin{array}{r}2,300 \\
1,800 \\
\end{array}$ \\
\hline 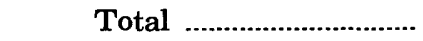 & $\overline{3,800}$ & $\overrightarrow{4,100}$ \\
\hline Total, $0-2,000 \mathrm{ft}(609$. & $\overline{\mathrm{m})}$ & \\
\hline
\end{tabular}

tons of estimated $\mathrm{Cr}_{2} \mathrm{O}_{3}$ reserves and 385,000 short tons of $\mathrm{Cr}_{2} \mathrm{O}_{3}$ production reported by Jackson (1968). Inclusion of the reserves yields a total of 10.7 million short tons of $\mathrm{Cr}_{2} \mathrm{O}_{3}$.

\section{SPECULATIVE COPPER-GOLD POTENTIAL}

Tertiary intrusive rocks of intermediate composition cut the Stillwater Complex on the East Boulder Plateau and intrude the Paleozoic and Mesozoic sedimentary rocks north of the complex. To the south in the headwaters of the Boulder River, Tertiary intrusive rocks are associated with the alteration and gold deposits of the Independence mining district (Iddings and Weed, 1894; Foose and others, 1961). Hess' (1960) descriptions suggested some alteration of the anorthosites and gabbros through which the intermediate rocks intruded. In view of this, it is possible that some hydrothermal activity may have been associated with the Tertiary intrusive bodies north of the complex and that this activity could have resulted in mineralization, such as copper-gold veins, disseminated deposits, or replacement deposits. On this basis, the area around and over the Tertiary intrusive bodies has been assigned a low copper-gold potential (fig. 1).

\section{IRON POTENTIAL}

The presence of iron-formation in the area extending from the West Fork of the Stillwater River to a point west of the Boulder River in the Precambrian metasedimentary rocks implies that some iron-resource potential exists. In the late 1950 's, the iron-formation was explored from Iron Mountain to Chrome Mountain by U.S. Steel, which subsequently dropped its claims (Dayton, 1971). The most intense exploration appears to 
have been in areas where the iron-formation is badly broken by faults and folds and thus where it is difficult to delineate continuous areas with large tonnages. Because of this intense deformation, most occurrences of iron-formation represent only a low to moderate resource potential. In the area west of the Boulder River to a point slightly east and south of Blakely Creek, however, the iron-formation is thicker and more continuous than elsewhere, and so it may have a higher potential.

\section{ALUMINUM POTENTIAL}

The $\mathrm{Al}_{2} \mathrm{O}_{3}$ content of the feldspars of the Upper zone is another potential resource in the Stillwater Complex. Feldspar is a possible source of aluminum if and when an economic process for the extraction of alumina from anorthosite becomes available. (See, for example, Ampian, 1967, and Leitch and others, 1965.) The Upper zone of the complex contains at least three anorthosite zones, each about 1,400 feet $(426.7 \mathrm{~m})$ thick, but the exact position of these zones has not been determined. Therefore, the entire Banded and Upper zones have been assigned a low to moderate resource potential for aluminum (fig. 1). The U.S. Bureau of Mines (1967) estimated this potential at approximately 1.8 billion tons of alumina by assuming the existence of a lens of anorthosite with a maximum thickness of 4,000 feet $(1,219.2$ $\mathrm{m}$ ) and a shape similar to that of the upper part of the complex. On the basis of the compiled geologic mapping and stratigraphic information, we estimate the resource potential to be nearly 7.7 billion tons of alumina to a depth of 1,000 feet $(304.8 \mathrm{~m})$ and 15.4 billion tons to 2,000 feet $(609.6 \mathrm{~m})$.

Although the Stillwater Complex is widest where Hess (1960) measured a "stratigraphic" section and narrows both to the east and to the west, field investigations indicate, at least to a first approximation, that two of Hess' anorthosite zones are virtually continuous and of relatively constant thickness throughout the 26-mile (41.8 $\mathrm{km}$ ) length of the complex. These investigations also indicate that the third zone is probably continuous for at least 17 miles $(27.4 \mathrm{~km})$. The composition of plagioclase from the anorthosites reported by Hess (1960) and the U.S. Bureau of Mines (1967) ranges from $\mathrm{An}_{75.5}$ to $\mathrm{An}_{79}$ and averages approximately $\mathrm{An}_{7 \tau}$. Chemical analyses (U.S. Bureau of Mines, 1967) indicate an average $\mathrm{Al}_{2} \mathrm{O}_{3}$ content of approximately 32 weight percent. Modal analyses (Hess, 1960) of the anorthosites show a range from 85 to 100 percent plagioclase and suggest an average of approximately 90 percent plagioclase. Other units appear to have remarkably consistent chemical and modal compositions throughout the length of the complex, and these properties are assumed constant for the anorthosites.

The estimate of the potential alumina resources (table 3 ) is also based on the assumption that (1)

TABLE 3.-Estimated potential aluminum resources for the anorthosites of the Stillwater Complex, in billions of short tons

\begin{tabular}{lrrr}
\hline Depth $(\mathrm{ft})$ & Anorthosite & $\begin{array}{c}\text { Alumina } \\
\left(\mathrm{Al}_{2} \mathrm{O}_{3}\right)\end{array}$ & Al \\
\hline $0-1,000(304.8 \mathrm{~m})$ & $\ldots \ldots \ldots \ldots . .26 .6$ & 7.7 & 2.7 \\
$0-2,000(609.6 \mathrm{~m})$ & $\ldots \ldots \ldots \ldots \ldots . .53 .2$ & 15.4 & 5.1 \\
\hline
\end{tabular}

the average density of the anorthosites is $174 \mathrm{lbs} /$ $\mathrm{ft}^{3},(2)$ the dip of the zone averages $60^{\circ}$, and (3) the average recovery rate for mining approximates 50 percent.

\section{COAL POTENTIAL}

In the northeastern corner of the Mount Wood quadrangle, along the inner valley of the Stillwater River, a coal-rich bed was mined during the latter part of the 19th century to serve local demands (Calvert, 1916). Vhay (1934) placed the coal stratigraphically at the top of a thick, massively bedded sandstone within the Upper Cretaceous Eagle Sandstone. Stratigraphic descriptions of the Eagle Sandstone and of the coal beds contained within it were presented for adjacent areas of Montana by Knappen and Moulton (1931) and by Roberts $(1966,1972)$. As described by Calvert (1916), the total thickness of the coal in the Stillwater area is approximately $3-5$ feet $(0.9-1.5 \mathrm{~m})$, and his analyses indicate that the coal is of high-volatile $B$ and $C$ bituminous ranks with a relatively low sulphur content (averaging about one-half of 1 percent). Combo, Brown, Pulver, and Taylor (1949) estimated the coal resources in the Stillwater area at approximately 12.7 million tons.

The coal resource of the Eagle Sandstone was estimated by extrapolations of available geologic and stratigraphic data (Calvert, 1916; Vhay, 1934) in the Stillwater area. Approximate structural contours were estimated for the coal-rich bed and were combined with the topographic relief 
to determine the potential area of coal in three depth ranges, $0-1,000$ feet $(304.8 \mathrm{~m}), 1,000-2,000$ feet $(609.6 \mathrm{~m})$, and $2,000-3,000$ feet $(914.4 \mathrm{~m})$. These area estimates were adjusted to resource estimates by using an averaged total coal thickness of 3 feet $(0.91 \mathrm{~m})$, a weight volume factor of $1,520,000$ tons per square mile-foot (equivalent to a specific gravity of 1.32 ), and a 50-percent recovery factor. Assumptions, definitions, and procedures used to prepare this estimate follow the conventions established by Averitt (1969).

The total estimated potential coal resource of the Stillwater area is approximately 50 million tons. This estimate is broken down by depth and local area in table 4, and part of the areal distribu-

TABLE 4.-Inferred coal resources, in millions of short tons, of the Stillwater area

[Rank, high-volatile $B$ and $C$ bituminous; bed thickness, 28-42 in.]

\begin{tabular}{|c|c|c|c|}
\hline Area & $\underset{(f t)}{\text { Overburden }}$ & $\begin{array}{l}\text { Recovery of } \\
100 \text { percent }\end{array}$ & $\begin{array}{l}\text { Recovery of } \\
50 \text { percent }\end{array}$ \\
\hline $\begin{array}{l}\text { Nye area, north of the } \\
\text { Stillwater River } \\
\text { (Mount Wood } \\
\text { quadrangle). }\end{array}$ & $\begin{array}{r}10-1,000 \\
21,000-2,000 \\
22,000-3,000\end{array}$ & $\begin{array}{r}4.8 \\
7.3 \\
11.1\end{array}$ & $\begin{array}{l}2.4 \\
3.7 \\
5.6\end{array}$ \\
\hline $\begin{array}{l}\text { Hypothetical: } \\
\text { South of the } \\
\text { Stillwater River, } \\
\text { north of Dean } \\
\text { Basin, and east of } \\
\text { Little Rocky Creek } \\
\text { (Beehive quadrangle) }\end{array}$ & $\begin{array}{r}0-1,000 \\
1,000-2,000 \\
2,000-3,000\end{array}$ & $\begin{array}{r}15.2 \\
13.7 \\
9.3\end{array}$ & $\begin{array}{l}7.6 \\
6.6 \\
4.6\end{array}$ \\
\hline $\begin{array}{l}\text { Speculative: } \\
\text { South of Dean Basin } \\
\text { (Beehive and Emerald } \\
\text { Lake quadrangles). }\end{array}$ & $0-3,000$ & $\sim 52$ & $\sim 26$ \\
\hline \multicolumn{3}{|c|}{ Total inferred resource ........................... 112.7} & 56.4 \\
\hline
\end{tabular}

tion is shown in figure 1. Because these estimates are based on sparse geologic data and only three measurements of coal-bed thickness, only the coal between 0 and 1,000 feet $(304.8 \mathrm{~m})$ in the Nye area is considered to be an indicated resource, and that between 1,000 and 3,000 feet $(914.4 \mathrm{~m})$ a hypothetical resource. In the Beehive and Emerald Lake quadrangles, the coal is a speculative undiscovered resource because no outcrops of coal have been found and large parts of the area are covered by Pleistocene and Holocene deposits.

\section{LIMESTONE AND DOLOMTTE, SAND, GRAVEL}

The other commodities present in the Stillwater area include limestone and dolomite, sand, and gravel. Limestone and dolomite occur in the Paleozoic sedimentary sequence that overlies the Stillwater Complex to the north and have been quarried from the Madison Limestone south of
Horseman's Flat for slagging material in the manufacture of ferrichrome alloy at the Mountain View mill. Therefore, some of the limestone and dolomite north of the Stillwater Complex has potential as a slagging material. Extensive glacial and alluvial debris cover large areas of the northern part of the Mount Wood quadrangle and have some potential for the local production of gravel and sand.

\section{ENERGY REQUIREMENTS}

In addition to the identification of areas where potential resources occur and the estimation of their magnitude, the energy requirements to extract and refine these resources also must be considered in their evaluation. The amount of energy needed to produce a metal could be a limit to identifying usable resources. Unfortunately, only a few estimates of energy expenditures as a function of the grade of ore have been made. Bravard, Flora, and Portal (1972) made such estimates for magnesium, aluminum, iron, copper, and titanium; their data are used here in examples to demonstrate the value of considering the energy expenditure.

Production of 1 ton of copper from 1.0 percent copper sulfide ore requires about $13,532 \mathrm{kWh}$ (kilowatt-hours) of equivalent coal energy, and about $24,759 \mathrm{kWh}$ of equivalent coal energy would be expended using a 0.3 percent copper sulfide ore (Bravard and others, 1972). At the lower grade over half of the energy is required for mining and milling, and because the amount of ore material necessary to produce a ton of copper is exponentially related to the grade of the material, it would seem possible that for ores of low grade the energy required would also increase exponentially and not be inversely proportional to grade, as assumed by Bravard, Flora, and Portal (1972). Their basic assumptions, however, indicate that copper-nickel sulfide ores of the Stillwater area containing 0.5 percent copper would require about $21,500 \mathrm{kWh}$ of equivalent coal energy per ton of copper to recover this potential resource. In order to mine and refine all the reserves reported in this area, $5.5 \times 10^{13} \mathrm{Btu}$ (British thermal units) of energy would be required, which may be compared with the low estimate of $3.27 \times 10^{18}$ Btu of total cumulative energy demand for the United States from the year 1968 to 2000 (U.S. Bureau of Mines, 1970 , p. 15). Because the energy expenditure is a small proportion of the energy available, the 
copper-nickel ores are apparently a usable potential resource, but only if technologic and economic conditions are satisfactory.

In contrast, the recovery of the $5.1 \times 10^{9}$ tons of aluminum from the anorthosites would require about $1.26 \times 10^{18} \mathrm{Btu}$ of energy, using the present technology. This is about one twenty-eighth of the total energy reserves of the United States (U.S. Bureau of Mines, 1970, p. 15), and the aluminum recovered would satisfy the contingency forecast of demand for aluminum well past the year 2000 for the world (U.S. Bureau of Mines, 1970, p. 455). Such a comparison, however, suggests little feasibility of recovering aluminum from this source, and the aluminum would be recoverable only after drastic changes in technology or economics. On the basis of Calvert's (1916) analyses of the coal, the local coal resource can supply only $2.13 \times 10^{11}$ Btu of energy from material between 0 and 1,000 feet $(304.8 \mathrm{~m})$, assuming 100 -percent recovery, and therefore would not be a large enough energy resource to mine and refine either the coppernickel or the aluminum.

According to Bravard, Flora, and Portal (1972, p. 25), between 4,270 and $10,295 \mathrm{kWh}$ of equivalent coal energy is required to produce 1 ton of iron, depending on the process and the ore grade. This is the lowest amount of energy required for production of metals studied by them and indicates that energy usage will not be a limiting factor in considering the potential iron resource in the Stillwater area. Energy requirements for using the chromium and platinum metal resources are not known but are believed to be between those of iron and aluminum. Therefore these potential resources cannot be evaluated in terms of energy requirements without further information.

\section{REFERENCES CITED}

Ampian, S. C., 1967, Limestone soda process-Correlation of reaction products with extractability of alumina from anorthosite: U.S. Bur. Mines Rept. Inv. 6933, $44 \mathrm{p}$.

Averitt, Paul, 1969, Coal resources of the United States, January 1967: U.S. Geol. Survey Bull. 1275, 116 p.

Bravard, J. C., Flora, H. B., 2d, and Portal, Charles, 1972, Energy expenditure associated with the production and recycle of metals: ORNL-NSF Environmental Program Rept. 24, Oak Ridge Natl. Lab., 87 p.

Brobst, D. A., and Pratt, W. P., 1973, Introduction, in United States mineral resources: U.S. Geol. Survey Prof. Paper 820 , p. 1-8.
Calvert, W. R., 1916, Geology of the Upper Stillwater Basin, Stillwater and Carbon Counties, Montana, with special reference to coal and oil: U.S. Geol. Survey Bull. 641-G, p. 199-214.

Combo, J. X., Brown, D. M., Pulver, H. F., and Taylor, D. A., 1949, Coal resources of Montana: U.S. Geol. Survey Circ. 53, 28 p.

Cornwall, H. R., 1966, Nickel deposits of North America: U.S. Geol. Survey Bull. 1223, 62 p.

Dayton, Stan, 1971, Hot air over Stillwater, profile of a hearing on mineral entry: Eng. and Mining Jour., v. 172 , no. 10 , p. $75-84$.

Foose, R. M., Wise, D. U., and Garbarini, G. S., 1961, Structural geology of the Beartooth Mountains, Montana and Wyoming: Geol. Soc. America Bull., v. 72 , p. 1143-1172.

Greenland, L. P., Rowe, J. J., and Dinnin, J. I., 1971, Application of triple coincidence counting and of fire-assay separation to the neutron-activation determination of iridium, in Geological Survey research 1971: U.S. Geol. Survey Prof. Paper 750-B, p. B175B179.

Grimaldi, F. S., and Schnepfe, M. M., 1969, Mode of occurrence of platinum, palladium, and rhodium in chromitite, in Geological Survey research 1969: U.S. Geol. Survey Prof. Paper 650-C, p. C149-C151.

Hess, H. H., 1960, Stillwater igneous complex, Montana -a quantitative mineralogical study: Geol. Soc. America Mem. 80, 230 p.

Howland, A. L., 1933, Sulphides and metamorphic rocks at the base of the Stillwater Complex, Montana: Princeton Univ., Princeton, N. J., Ph. D. thesis, 76 p.

Howland, A. L., Peoples, J. W., and Sampson, Edward, 1936, The Stillwater igneous complex and associated occurrences of nickel and platinum metals: Montana Bur. Mines and Geology Misc. Contr. 7, 15 p.

Iddings, J. P., and Weed, W. H., 1894, Description of the Livingston Atlas Sheet [Montana]: U.S. Geol. Survey Geol. Atlas, Folio 1.

Jackson, E. D., 1961, Primary textures and mineral associations in the ultramafic zone of the Stillwater Complex, Montana: U.S. Geol. Survey Prof. Paper 358, $106 \mathrm{p}$.

1968, The chromite deposits of the Stillwater Complex, Montana, in Ore deposits of the United States, 1933-1967 (Graton-Sales volume), v. 2: New York, Am. Inst. Mining, Metall., and Petroleum Engineers, p. 1495-1510.

Jones, W. R., Peoples, J. W., and Howland, A. L., 1960, Igneous and tectonic structures of the Stillwater Complex, Montana: U.S. Geol. Survey Bull. 1071-H, p. 281-340.

Knappen, R. S., and Moulton, G. F., 1931, Geology and mineral resources of parts of Carbon, Bighorn, Yellowstone, and Stillwater Counties, Montana: U.S. Geol. Survey Bull. 822, p. 1-70.

Leitch, H., Iverson, H. G., and Clemmer, J. B., 1965, Extraction of alumina by leaching melted, and quenched anorthosite in sulfuric acid: U.S. Bur. Mines Rept. Inv. $6744,32 \mathrm{p}$. 
Leonard, B. F., Desborough, G. A., and Page, N. J, 1969, Ore microscopy and chemical composition of some laurites: Am. Mineralogist, v. 54, p. 1330-1346.

McKelvey, V. E., 1973, Mineral resource estimates and public policy, in Brobst, D. A., and Pratt, W. P., eds., United States mineral resources: U.S. Geol. Survey Prof. Paper 820, p. 9-19.

Page, N. J, 1971, Sulfide minerals in the $\mathrm{G}$ and $\mathrm{H}$ chromite zones of the Stillwater Complex, Montana: U.S. Geol. Survey Prof. Paper 694, 20 p.

Page, N. J, Clark, A. L., Desborough, G. A., and Parker, R. L., 1973, Platinum-group metals, in Brobst, D. A., and Pratt, W. P., eds., United States mineral resources: U.S. Geol. Survey Prof. Paper 820, p. 537545.

Page, N. J, and Jackson, E. D., 1967, Preliminary report on sulfide and platinum-group minerals in the chromitites of the Stillwater Complex, Montana, in Geological Survey research 1967: U.S. Geol. Survey Prof. Paper 575-D, p. D123-D126.

Page, N. J, and Nokleberg, W. J., 1970, Preliminary geologic map of the Stillwater Complex, Montana: U.S. Geol. Survey open-file report.

1972, Preliminary geologic map of the west-central and western parts of the Stillwater Complex, Montana: U.S. Geol. Survey open-file report.

Page, N. J, Riley, L. B., and Haffty, Joseph, 1969, Platinum, palladium, and rhodium analyses of ultramafic and mafic rocks from the Stillwater Complex, Montana: U.S. Geol. Survey Circ. 624, 12 p.

-1971, Lateral and vertical variations of platinum, palladium, and rhodium in the Stillwater Complex, Montana [abs.] : Geol. Soc. America Abst. with Programs, v. 3 , no. 6 , p. 401 .

1972, Vertical and lateral variation of platinum, palladium, and rhodium in the Stillwater Complex, Montana: Econ. Geology, v. 67, no. 7, p. 915-924.

Page, N. J, Shimek, Richard, and Huffman, Claude, Jr., 1972, Grain-size variations within an olivine cumulate, Stillwater Complex, Montana, in Geological Survey research 1972: U.S. Geol. Survey Prof. Paper 800-C, p. C29-C37.
Page, N. J, Simons, F. S., and Dohrenwend, John, 1973a, Reconnaissance geologic map of the Mount Douglas quadrangle, Montana: U.S. Geol. Survey Mineral Inv. Field Studies Map MF-488.

$1973 \mathrm{~b}$, Reconnaissance geologic map of the Mount Wood quadrangle, Montana: U.S. Geol. Survey Mineral Inv. Field Studies Map MF-491.

Peoples, J. W., 1936, Gravity stratification as a criterion in the interpretation of the structure of the Stillwater Complex, Montana: Internat. Geol. Cong., 16th, Washington, D.C., 1933, Rept. v. 1, p. 353-360.

Roberts, A. E., 1966, Geology and coal resources of the Livingston coal field, Gallatin and Park Counties, Montana: U.S. Geol. Survey Prof. Paper 526-A, 56 p. 1972, Cretaceous and early Tertiary depositional and tectonic history of the Livingston area, southwestern Montana: U.S. Geol. Survey Prof. Paper 526-C, 120 p.

Theobald, P. K., Schweinfurth, S. P., and Duncan, D. C., 1972, Energy resources of the United States: U.S. Geol. Survey Circ. 650, 27 p.

U.S. Bureau of Mines, 1967, Potential sources of aluminum: U.S. Bur. Mines Inf. Circ. 8335, 146 p.

-1970 , Mineral facts and problems: U.S. Bur. Mines Bull. 650, 1291 p.

U.S. Geological Survey, 1971, Aeromagnetic map of the Stillwater Complex and vicinity, south-central Montana: U.S. Geol. Survey open-file report.

Vhay, J. S., 1954, Geology of part of the Beartooth Mountain front near Nye, Montana: Princeton Univ., Princeton, N. J., Ph. D. thesis.

Westgate, L. G., 1921, Deposits of chromite in Stillwater and Sweet Grass Counties, Montana: U.S. Geol. Survey Bull. 725, p. 67-84.

Wimmler, N. L., 1948, Investigation of chromite deposits of the Stillwater Complex, Stillwater and Sweetgrass Counties, Montana: U.S. Bur. Mines Rept. Inv. RI-4368, 41 p. 
